International Journal of Current Advanced Research

ISSN: O: 2319-6475, ISSN: P: 2319 - 6505, Impact Factor: SJIF: 5.995

Available Online at www.journalijcar.org

Volume 6; Issue 3; March 2017; Page No. 2697-2698

DOI: http://dx.doi.org/10.24327/ijcar.2017.2698.0080

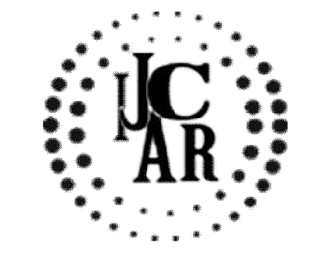

Research Article

\title{
INCREASING TREND OF JUNK FOOD USE IN COLLEGE STUDENTS AND HEALTH IMPLICATIONS
}

\author{
R.Jagadish Rajkumaar and Preetha.S
}

Saveetha dental college and hospitals Chennai-600 077

\section{A R T I C L E I N F O}

\section{Article History:}

Received $28^{\text {th }}$ December, 2016

Received in revised form $6^{\text {th }}$ January, 2017

Accepted $15^{\text {th }}$ February, 2017

Published online $28^{\text {th }}$ March, 2017

\begin{abstract}
A B S T R A C T
To do a survey and find out the reach of junk foods among the college going students and to create awareness among the college students about junk food and its health implications. The questionnaire consist of 20 questions and the sample size was taken for 100 college students. Junk foods are loaded with lots of fat, sugar, calories, salt and carbs and therefore are not very healthy. Eating excessive amount of junk food leads to obesity and malnutrition. It also cuts down the energy levels of the body.Junk foods contain high amount of oil and fat and therefore our body finds it difficulty to digest.This survey concludesthe students to be less aware of the ill effects of junk foods.
\end{abstract}

Copyright $\mathrm{C} 2017$ R.Jagadish Rajkumaar and Preetha.S. This is an open access article distributed under the Creative Commons Attribution License, which permits unrestricted use, distribution, and reproduction in any medium, provided the original work is properly cited.

\section{INTRODUCTION}

The term 'Junk food' was termed by Michael jacobson. Junk food is produced with high level of refined sugar, white flour, polyunsaturated fats, salts and numerous food additives but lacking in protein, vitamin and fibres.Junk food is popular because of their simplicity of manufacture, consumption and good taste. There is increasing trend of junk food use which is Combined with lavish life style, high prevalence of obesity, diabetes mellitus, hypertension and coronary heart disease, which is harmful to health and will aggravate existing life style diseases in students. [1] The common junk foods include fast food items, chips, candy, gum, sweet desserts as well as alcoholic beverages. [9] Consumption of energy dense foods especially sweetened beverages like fruit drinks, carbonated soft drinks and energy drinks may lead to type 2 diabetes and cardiovascular risk. [3] The frequency of fast-food intake was not found to be significantly associated with perceived healthfulness of such food. [3] Trends including fast food consumption and such dietary behaviours are associated with increased weight gain from adolescence to adulthood. Ill effects of regular intake of junk foods cause lack of energy, poor concentration and obesity leading to inferiority complex, depression, heart diseases, high cholesterol, stunted growth, premature ageing, and tooth decay as per [2]. [4] The negative effects of consumption of excess salt containing junk foods on health include increase in blood pressure and decrease in

*Corresponding author: R.Jagadish Rajkumaar

Saveetha dental college and hospitals Chennai-600 077 containing food additives causes' serious health effects on people with renal disorders. [8] Sometimes food additives are added to junk food to increase the shelf life, taste and also to preserve it from microbial contamination. The internal barriers to nutritional change include negative perceptions of eating healthy, the decreased taste, difficulty in changing familiar eating habits, eating for comfort, and the priority to mental health. [7] High salt content foods can be addictive substances that stimulate the dopamine receptors in the brain, leading to increase in craving and hunger. [10] It leads to increased appetite, calorie consumption, overeating, obesity and related illness.

\section{MATERIALS AND METHODS}

A study was conducted among 100 college going students of the age group 18-22 with the help of a survey containing 20 questions and prior to this the students were given a brief overview about junk foods and their ill health effects. They were future given time to answer theresponses and by the help of the data collected the respective results were concluded.

Initially, the students were asked if they preferred eating junk food and $64 \%$ of the students preferred eating junk foods.Next when they were enquired about the place where they consumed more junk food, the responses were $71 \%$ of the students responded that they ate more junk foods only at malls and restaurants and $20 \%$ of the students ate junk foods at college or school canteen whereas only $9 \%$ said that they were more exposed to junk foods at Home. And finally through this survey $92 \%$ of the ned knowledge about the health implications caused by junk foods. 


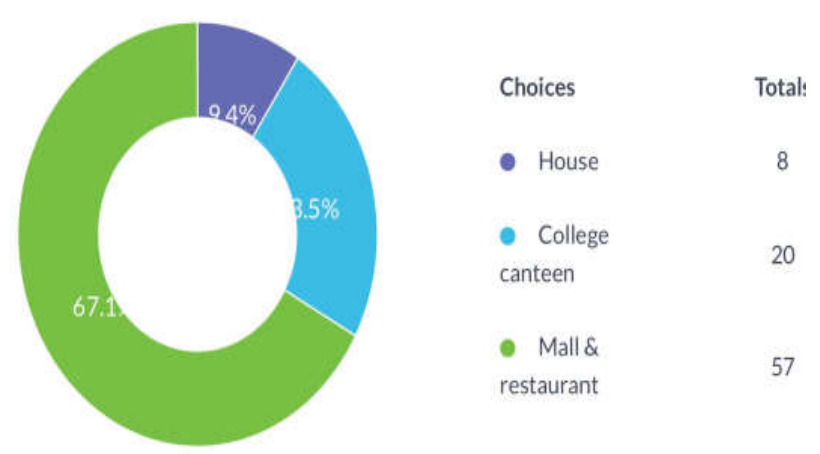

Fast food has become a prominent feature of the diet of children in India and, increasingly, throughout the world. The results of this study is in line with the findings of Satia et al., [6] who reported that responders who reported usual/often eating at fast-food restaurants were more often the younger generation and the main cause of such situation is the developmental factors that include more time spent with peers, independence in meal selectionand this study also finds maximum students to be fond of junk foods and $33 \%$ of the students were not interested in junk foods. [11] Junkfoods cause various types of cancers such as stomach cancer, breast cancer in women, colorectal cancer etc $64 \%$ of the students agreed that junk foods caused cancer in the longer run whereas $21 \%$ of the students were not aware that cancers are now predominant because of junk foods. More number of respondents were now aware that cancer could be caused due to consumption of junk food. The findings of this study corresponds with the findings of Chibber [2] who reported that the ill effects of regular intake of junk foods are mainly lack of energy, poor concentration and obesity leading to inferiority complex, depression, heart diseases, high cholesterol, stunted growth, premature ageing, and tooth decayand $67 \%$ of the students were aware that junk foods caused heart disease and $22 \%$ disagreed to this fact saying that junk food can cause damage to the heart and $10 \%$ of the students were not actually sure about it . This study finds $57 \%$ of the students still consumed junk foods even after knowing that junk food caused type 2 diabetes. $65 \%$ of the students were aware that junk foods caused hypertension and hyper cholesterol ailments.

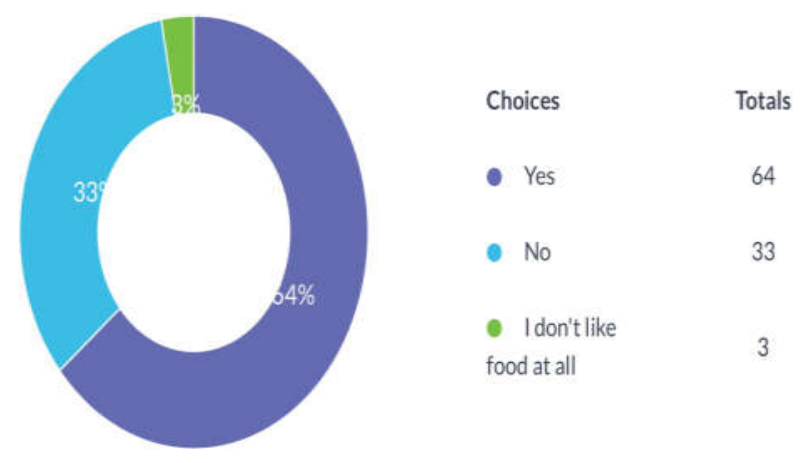

\section{CONCLUSION}

The focus of my finding include the views of adolescents on junk foods, individual preferences, consumption rates and familiarity regarding the harmful health effects of overconsumption of junk food products. From our study we have identified certain factors responsible for increased eating habits of junk food include the new unhealthy trends introduced in the foods that we get these days and another factor that supports the sales of these foods is that they are available cheap and they are tasty too it would be recommended that if high taxes were imposed on these foods the consumption of healthy foods may rise to an extent thereby promoting healthy living. There is a defiant need for the young generation of teens to understand the facts and various complications caused by junk foods.

\section{References}

1. Dr. ZahidNaeem, Increasing trend of Junk food use in Saudi Arabia and health implications, Int J Health Sci (Qassim). 2012 Jan; 6(1): V-VI. [pubmed]

2. VinayGopal J.1, Sriram S.2, Kannabiran K.3 and Seenivasan R.4, Student's perspective on junk foods: Survey

3. Carter OB, Patterson LJ, Donovan RJ, Ewing MT, Roberts CM. Children's understanding of the selling versus persuasive intent of junk food advertising: implications for regulation. SocSci Med. 2011 Mar;72(6):962-8. Epub 2011 Feb 23. [PubMed]

4. Cizza G, Rother KI. Beyond fast food and slow motion: weighty contributors to the obesity epidemic. J Endocrinol Invest. 2012 Feb;35(2):23642. Epub 2011 Dec 15.

5. Niemeier HM, Raynor HA, Lloyd-Richardson EE, Rogers ML, Wing RR. Fast food consumption and breakfast skipping: Predictors of weight gain from adolescence to adulthood in a nationally representative sample. $J$ Adolesc Health. 2006;39:842-9.

6. J.A. Satia, J.A. Galanko, A.M. Siega-Riz, (2004). Eating at fast food restaurants is associated with dietary intake, demographic, psychosocial and behavioural factors among African Americans in North Carolina. Public Health Nutrition, 7, 10891096

7. Asgary S, Nazari B, Sarrafzadegan N, Parkhideh S, Saberi S, Esmaillzadeh A, et al. Evaluation of fatty acid content of some Iranian fast foods with emphasis on trans fatty acids. Asia Pac J ClinNutr. 2009; 18: 187-92.

8. Printice AM, Jebb SA. Fast foods, energy density and obesity: a possible mechanistic link. Obesity Rev. 2003;4:187-94.

9. Schmidt M, Affenito SG, Streigl-Moore R, Khoury PR, Barton B, Crawford P, et al. Fast food intake and diet.

10. Tandon PS, Wright J, Zhou C, Rogers CB, Christakis DA. Nutrition menu labeling may lead to lowercalorie restaurant meal choices for children. Pediatrics. 2010;125: 244-8.

11. Demory-Luce D. Fast food and children and adolescents: implications for practitioners. ClinPediatr(Phila) 2005 May;44(4):279-288. [PubMed] 